ley) was considered probably Triassic. And another portion of this plant series (in Kutch) was found associated with a marine fauna ranging from the age of the Bath Oolite up to the Tithonian of Continental geologists.

On the whole question, the Triassic fossils, though their suggestiveness was admitted, were not considered sufficient to have much influence, and to the upper part of the plant-beds a Jurassic age was assigned, while the lower portion, apparently on the evidence of the Glossopteris, was thought to be Palæozoic, an opinion, however, which does not appear to have been universally received.

In this state, or one very similar, Dr. Feistmantel found the subject upon commencing his examination of the Indian fossil plants, aided by the separation of the series into several groups on stratigraphical grounds by the officers of the Geological Survey.

His examination has led to results so far as yet published, which will be found in two papers among the Recorlls of the Geological Survey (vol. ix., parts 2, 3).

From these it appears he considers the Kutch flora to represent a period in the Jurassic epoch somewhat earlier than that indicated by the associated marine fauna, so far as this has been examined, which is one of the points in debate, and that five of the upper divisions of the Indian plant beds (or Gondwana series) are Jurassic, while he contends that the remaining three of its lower groups are neither Jurassic nor Carboniferous, but Triassic.

In a paper immediately following Dr. Feistmantel's second contribution to the Records of the Indian Survey, Mr. W. T. Blanford discusses the whole question, and arrives at the conclusion that the evidence connecting the lower Indian plant beds with the Australian carboniferous rocks is about equal to that for their being of the same age as the Trias of Europe-pointing out that the land faunas and floras of Palæozoic and Mesozoic times differed from each other in different parts of the globe, at least as much as they do at present, and far more than the fauna of the sea. Also that the evidence founded upon fossil plants of the age of rocks in distant regions must be received with great caution, being certainly in same cases opposed to that furnished by the [contemporaneous] marine fauna.

In a coming volume of the "Pałæontologia Indica," Dr. Feistmantel will no doubt state his views and their reasons as fully as possible; meantime, enough has been said to show the interesting, yet rather difficult, nature of the subject, for more detail regarding which the papers just mentioned may be referred to.

\section{THE RIVER CLYDE}

THE profession of Civil Engineering, as defined by Telford, which definition is incorporated into the Charter of the Institution of Civil Engineers, is "the art of directing the great sources of power in Nature for the use and convenience of man," and there are few more striking examples of what science may do for commerce, or of what man may accomplish by working hand-in-hand with Nature than is the proud position of the River Clyde at the present day, as compared to what it was one hundred years ago, or even as late as the year 1840 .

To many of those who attended the recent meeting of the British Association, and who have fresh in their memory the geography of the City of Glasgow, with which must indissolubly be connected the princely hospitality of its inhabitants, it may be interesting to know that the noble river which has made Glasgow the mighty city that it is, from whose shores some of the largest ironclads of our fleet have been launched is a water highway, almost as much the work of man as is the Suez Canal itself.

One hundred years ago the Clyde was little more than a picturesque mountain-stream, so shallow, that at a place called Dumbuck Ford, twelve miles below Glasgow Bridge, passengers could traverse it on foot. Now, vessels drawing twenty-three feet of water can ride safely in the heart of the city at low water, and the largest ocean-going steamers can come up the river at all times of the tide.

This wonderful change has been brought about by a succession of engineering operations, in all of which Nature has been coaxed, by artificial means, into doing the largest share of the work; and the operations of man, great as they have been, have been directed solely to assist that work, and to remove obstacles which stood in its way. The names of the engineers under whose directions these improvements have been made, alone show that the highest scientific skill has been brought to bear upon the development of the water-way to the City of Glasgow; for, within the last 100 years, among the engineers who have been employed by the Clyde trustees, either to carry out improvements, or to prepare reports in connection therewith, will be found the names of Smeaton, Golborne, Watt, Sir John Rennie, Telford, Stevenson, Walker, Scott Russeli, and Bateman; but the largest engineering operations have been left for Mr. Deas, the present engineer of the Clyde navigation to carry out, for since the year 1872 greater progress has been made than during any previous equal period. In that time no less than 1,505 lineal yards of quayage have been added, slip and gravingdocks have been constructed, large cranes erected, and very considerable progress towards completion has been made in the celebrated Stobcross Docks of which we shall speak further on.

The exceptional construction of these docks, necessitated by the local peculiarities of the geological strata, formed the subject of a valuable paper read before the British Association by Mr. James Deas, C.E., under whose directions they are being constructed, and who has recently published a most interesting work upon the Clyde, illustrated with maps, sections, and tidal diagrams, and from which many of the data contained in this article have been derived, and to which we would refer those of our readers who wish for further investigation.

it is just a hundred and eight years ago since John Golborne, of Chester, visited the Clycle and macie his frst report, in which he pointed out that the shores of the river "in most places being much softer than the bottom, the current has operated there, because it could not penetrate the bed of the river, and has by those means gained in breadth what is wanting in depth ;" and, he added, "I shall proceed on these principles of assisting Nature when she cannot do her own work, by removing the stones and hard gravel from the bottom of the river where it is sha!low, and by contracting the channel where it is worn too wide."

Golborne, carrying these principles into practice, erected a number of rubble jetties so as to contract the channel, giving to the stream greater rapidity, and consequently greater scouring power, and by a system of dredging in the deeper shallows, and horse-ploughing in those which were exposed at low water, he loosened the hard crust forming the bed of the river, exposing to the action of the current the softer material below, which was speedily scoured away, and in less than eight years the depth of water at Dumbuck Ford was increased from 2 feet to F4 feet. Golborne was followed by Rennie, who, in I799, recommended the shortening of some of the jetties, the lengthening of others, and the construction of new ones, so as to direct the channel in its proper course with the least obstruction to the water ; and to insure this he recommended building rubble walls from point to point of the jetties, so as to avoid the formation of shoals between them. These suggestions were carried out by the Clyde

I "The River Clyde ; an Historical Description of the Rise and Progress of the Harbour of Glasgow." By James Deas, M. Inst.C.E. (Glasgow : James Mac!ehose, 1876 . 
trustees, and upwards of 200 jetties were thrown out between Glasgow Bridge and Bowling, a distance of eleven miles. During the next forty years improvements continued to be carried on, and the names of Telford and Rennie appear again in connection with them. In 1836 a report of Mr. Walker, the engineer to the navigation at that time, showed that there was a depth of water at the Broomielaw, just below Glasgow Bridge, of 8 feet at low water, and he adds that "the river which bv artificial means was to be rendered capable of taking craft of thirty to forty tons to Glasgow, has, by what Golborne called 'assisting Nature,' been rendered capable of floating vessels nearly ten times the burthen." But improvement did not stop here. Since that date the Harbour of Glasgow has been widened by 240 feet, and vessels of 3,000 tons burthen can float where at that time stood one of the largest cotton mills in the city.

Some very curious phenomena connected with the tides have resulted from the alterations of the tidal channel produced by these engineering operations. The level of low water in Glasgow Harbour has been getting lower and lower, until it is now no less than 8 feet lower than it was in 1758 , and during the last fourteen years there has been a depression of level of over a foot. This has been accompanied during the same period by a corresponding rise in the level of high water at ordinary spring tides. These phenomena are no doubt due to the greater facility with which the tidal wave can pass up and down the river than formerly, its shallow, broken, irregular, and tortuous channel having been straightened and deepened, and obstructions offering resistance to its flow having been removed. The increase of the rapidity of the flow is as remarkable as the increase of the volume of water. In the year 1807 the time of high water was three hours later at Glasgow than at Greenock, thirty years after there was a difference of $\mathrm{I}$ hour 23 minutes, and at the present time that difference has been reduced to $I$ hour and 5 minutes. At Greenock the tide flows for about $6 \frac{1}{4}$ hours and ebbs for about 6 hours, whereas at Glasgow it flows for $5 \frac{3}{4}$ hours and ebbs for $6 \frac{3}{4}$ hours.

In the improvements of the Clyde the one principle followed by all the engineers has been the increasing of the volume of the tidai wave and the prolonging of its flow into the upper reaches of the river. Very little work has been done by the natural fresh-water stream, although that is estimated at an average of 48,000 cubic feet per minute, which represents in round numbers over 300 million gallons for every twenty-four hours. This fact demonstrates very forcibly that it is to the tidal ebb and flow that we must lock for the conservation of the channels of tidal rivers, rather than to the action of the landwater, which cannot be depended upon for constancy, and its tendency is more often to deposit than to scour.

To keep the channel of the Clyde in order, constant dredging all the year round has to be maintained, and under the able administration of the engineer to the navigation this has been brought to a high state of perfection, both in amount of work done and in its very small cost, averaging as it does from about one shilling per cubic yard for gravel to $2 \frac{1}{2} d$. per cubic yard for sand, and these costs are inclusive of repairs

Although the Trustees already possess the largest steam-dredging fleet in the world, they have lately given to Messrs. Rait and Lindsay, of Glasgow, whose firm has a world-wide reputation for the construction of such plant, an order for four new steam hopper barges, thus bringing the number up to eighteen. These vessels are designed by $\mathrm{Mr}$. Deas, and will measure I 50 feet long, 26 feet wide, and 12 feet deep, and each capable of carrying 500 tons of dredged material. They will be fitted with compound high and low pressure engines, which will also be constructed by Messrs. Rait and Lindsay.

Dredging is employed for widening the river as well as for deepening the bed. When a bank has to be cut away the dredger is worked close to it so as to undermine it, and by this means much cost of excavation is saved.

For the removal of boulders, some of which weigh over six tons, diving bells are employed. Last year one bell lifted no less than 656 tons of boulders from the bed of the river. These bells are also employed for removing the débris resulting from sub-aqueous blasting operations which are continually going on, both dynamite and gunpowder being employed for the removal of Whinstone or trap rock. The charges are contained in tin canisters, which are inserted in holes of 3 inches diameter drilled in the rock, which are afterwards sealed up with Portland cement. They are fired in groups by a voltaic battery on the deck of the diving-bell barge, and the shattered rock is removed by the bells.

To give an idea of the benefits which engineering operations of this kind can confer upon the community, it is interesting to notice that whereas the reports of Smeaton, Telford, and Rennie, showed that the river was navigable only for barges to Glasgow, at the present time the registered export and import tonnage of Glasgow amounts to $2 \frac{1}{2}$ million tons, or equal to half the tonnage of London or of Liverpool. Population statistics point to the same result. In 1831 the population of Glasgow numbered 202,000, in I86I it had risen to 395,000 , and it is estimated at the present time at 535,000 .

The great increase of the shipping trading into the Port of Glasgow has had to be met by the extension of quays and by the construction of docks. The first of these, Kingston Dock, was o.:ened in 1867 , giving about $5 \frac{1}{2}$ acres of water-space, but the Trustees are now constructing docks at Stobcross which will have an area of over thirty-three acres, and capable of accommodating I,000,000 tons of shipping. A graving dock 560 feet long and 72 feet wide, with a depth of water of 22 feet, has also lately been opened.

The Stobcross Docks possess an especial scientific interest from the fact that the quay walls are supported on groups of concrete cylinders, a system of sub-aqueous foundation adopted here for the first time by the Clyde Trustees at the recommendation of Mr. J. F. Bateman and $\mathrm{Mr}$. James Deas, and the results have proved so eminently successful that this system is likely to be universally employed for dock foundations in sandy or gravelly soils. During the execution of this work the variety of the geological strata was particularly interesting, ranging as it did from boulder clay of the most tenacious character to the finest and sharpest of sand, much of which was used for the manufacture of glass.

The concrete cylinders are arranged in groups of three together, and are built up of rings formed in movable wooden moulds; they are 27 feet 6 inches in height, made up of eleven rings each, and rest upon iron shoes. When a group of three cylinders is built up to its height, diggers specially designed for the purpose are set to work excavating the sand and gravel from within the cylinders; as this comes away the whole structure disappears into the ground, being helped in its descent by the addition of about 300 tons of cast-iron weights placed on the top. The average rate of sinking is about $r$ foot per hour, but as much as 5 feet per hour has occasionally been attained. When the group has been sunk it is cleaned out by the diggers to the level of the shoe, each cylinder is then filled with Portland cement concrete, and upon this foundation the quay wall is built.

Want of space will not allow us to describe the hydraulic swing bridge which will cross the entrance from the river, nor to do more than mention the powerful hydraulic cranes built upon a similar foundation to that of the quays. For these and many other particulars of great interest in connection with the River Clyde we must refer our readers to Mr. Deas's book and to his paper "On the Construction of the Stobcross Docks," read before Section $G$ of the British Association. 